\title{
Kwantyfikacja przedsiębiorczości kraju z wykorzystaniem narzędzi taksonomii relatywnej: przykład państw Unii Europejskiej
}

\author{
Agnieszka Głodowska
}

\begin{tabular}{|c|c|}
\hline \multicolumn{2}{|r|}{ A B STRAKT } \\
\hline \multicolumn{2}{|c|}{$\begin{array}{l}\text { Cel artykułu: Celem artykułu jest przedstawienie i zweryfikowanie zaproponowanej } \\
\text { metody kwantyfikacji przedsiębiorczości na poziomie kraju. Zaproponowana metoda } \\
\text { wpisuje się w instrumentarium taksonomii relatywnej, a jaj egzemplifikacja zostanie } \\
\text { przeprowadzona na grupie krajów Unii Europejskiej (UE26) bez Malty i Grecji. }\end{array}$} \\
\hline \multicolumn{2}{|c|}{$\begin{array}{l}\text { Metodyka badań: W części teoretycznej jako metodę badawczą wykorzystano kry- } \\
\text { tyczną analizę literatury, zaś w części empirycznej metody statystyczne i taksono- } \\
\text { miczne. Do ewaluacja poziomu przedsiębiorczości krajowej zastosowano miarę } \\
\text { względną (inaczej relatywną, syntetyczną). Badanie przeprowadzono na grupie krajów } \\
\text { Unii Europejskiej (bez Malty i Grecji). Okres badawczy to lata 2011-2016 lub 2012-2017. }\end{array}$} \\
\hline \multicolumn{2}{|c|}{$\begin{array}{l}\text { Wyniki: Wyniki badań potwierdziły zasadność stosowania miary relatywnej w tego typu } \\
\text { badaniach. Takie podejście pozwala na ujęcie wielowymiarowości przedsiębiorczości } \\
\text { kraju, jak również porównywanie badanych krajów i ich hierarchizowanie. W badanej } \\
\text { grupie widoczne jest umiarkowane zróżnicowanie przedsiębiorczości. Najwyższy po- } \\
\text { ziom przedsiębiorczości widoczny jest w Estonii, Holandii i Wielkiej Brytanii, zaś najniż- } \\
\text { szy we Włoszech, Portugalii I Hiszpanii. }\end{array}$} \\
\hline \multicolumn{2}{|c|}{$\begin{array}{l}\text { Wkład i wartość dodana: Wartością dodaną artykułu jest zaproponowanie metody ewa } \\
\text { luacji przedsiębiorczości krajowej - poziom makro. Dzięki temu dokonano porządkowa } \\
\text { nia i porównania przedsiębiorczości krajów Unii Europejskiej. W literaturze odczuwalny } \\
\text { jest brak tego typu opracowań empirycznych. Stanowi to tym samym wkład w rozwó } \\
\text { badań w dyscyplinie ekonomia międzynarodowa (przedsiębiorczość międzynarodowa). }\end{array}$} \\
\hline cykułu: & \\
\hline & \\
\hline & \\
\hline \multicolumn{2}{|c|}{ Artykuł nadesłano: 3 lutego 2019} \\
\hline
\end{tabular}

\section{Sugerowane cytowanie:}

Głodowska, A. (2019). Kwantyfikacja przedsiębiorczości kraju z wykorzystaniem narzędzi taksonomii relatywnej: przykład państw Unii Europejskiej. International Entrepreneurship Review (previously published as International Entrepreneurship / Przedsiębiorczość Międzynarodowa), 5(1), 23-38. https://doi.org/10.15678/IER.2019.0501.02 


\section{WPROWADZENIE}

Przedsiębiorczość to problem badawczy odnoszący się do jednostek, organizacji, przemysłów, regionów i społeczeństw. Może mieć on zatem wymiar mikro, mezo i makro. Prowadzenie międzynarodowych badań porównawczych na temat przedsiębiorczości wpisuje się w nurt rozważań przedsiębiorczości międzynarodowej. Komparatystyka jako składowa przedsiębiorczości międzynarodowej wskazywana jest przez wielu autorów (Jones, Coviello, \& Tang, 2011; McDougall \& Oviatt, 1997; Wach, 2012; 2018; Wach \& Wehrmann, 2014). Porównywanie przedsiębiorczości na poziomie kraju nastręcza jednak wiele problemów natury metodycznej. Trudno bowiem znaleźć odpowiednią miarę, która ujęłaby kompleksowo badane zagadnienie, tym bardziej, że na poziomie makro jest to bardzo złożony problem. W dotychczasowych opracowaniach stosuje się najczęściej miarę zaprezentowaną w ramach Globalnego Monitora Przedsiębiorczości - Global Entrepreneurship Monitor (GEM) lub wybrane pojedyncze wskaźniki (samozatrudnienie, rodząca się przedsiębiorczość - Total Early - Stage Entrepreneurial Activity (TEA)). Nie są to jednak do końca kompletne sposoby ewaluacji przedsiębiorczości krajowej, czyli przedsiębiorczości na poziomie makro. Biorąc to pod uwagę niniejszy artykuł ma na celu zaprezentowanie sposobu kwantyfikacji przedsiębiorczości na poziomie kraju - poziom makro - za pomocą wybranej metody taksonomii relatywnej. Zastosowanie miar względnych do szacowania poziomu przedsiębiorczości pozwala na ujęcie jej wielowymiarowości, jak również porównywanie badanych krajów i ich hierarchizowanie. Jako przedmiot badań przyjęto grupę krajów Unii Europejskiej bez Malty i Grecji ze względu na brakujące dane dotyczące tych gospodarek. Analizę przeprowadzono dla okresu 2011-2016 lub 2012-2017 w zależności od dostępności danych statystycznych. Metoda badawcza wykorzystana w pracy to analiza krytyczna i synteza literatury przedmiotu oraz metody statystyczne i taksonomiczne.

Praca podzielona została na sekcje tematyczne. W części pierwszej dokonano przeglądu literatury z zakresu przedsiębiorczości międzynarodowej i biznesu międzynarodowego. W części drugiej zaprezentowano zastosowaną metodę badawczą. Cześć trzecia zwiera prezentację wyników badań na temat przedsiębiorczości krajów Unii Europejskiej i ich omówienie.

\section{METODYKA BADAWCZA}

Celem artykułu jest przedstawienie i zweryfikowanie sposobu kwantyfikacji przedsiębiorczości kraju za pomocą narzędzi taksonomii relatywnej. Pojęcie taksonomii relatywnej wprowadził do literatury profesor Wydymus (2013) w pracy na temat poziomu rozwoju gospodarczego i wynagrodzeń w krajach Unii Europejskiej. Kategoria ta należy do metod analizy wielowymiarowej opartej na zasadach taksonomii numerycznej. Istota metod taksonomicznych polega na budowie indeksu zagregowanego na podstawie wielu wytypowanych zmiennych diagnostycznych opisujących badane zjawisko. Jest ona adekwatna do ewaluacji zjawisk i procesów wielowymiarowych. Ma zatem użyteczne uzasadnienie do pomiaru przedsiębiorczości. Punktem wyjścia w tego typu analizie jest dobór zmiennych diagnostycznych, których wartość informacyjna transponowana jest za pomocą wybranych algorytmów do zagregowanej miary syntetycznej. Istnieje wiele metod budowy miar syntetycznych - zagregowanych. Większość z nich bazuje na podejściu liniowym, które, jak wskazuje Wydymus (2013), ma wiele merytorycznych mankamentów. Przede wszystkim 
uniemożliwia ono względną ocenę pozycji i dystansu danego kraju w stosunku do innych porównywanych, co z kolei jest możliwe przy zastosowaniu taksonomii relatywnej. Do wyznaczania relatywnej miary, którą inaczej nazywać można miarą syntetyczną, badanego zjawiska można zastosować różne algorytmy. W niniejszym artykule zastosowano metodę sum standaryzowanych (Mikuła, 2016). Biorąc pod uwagę to, że wytypowane zmienne diagnostyczne są stymulantami, ostatecznie w pracy wykorzystano następującą formułę:

$$
\begin{gathered}
Q_{i}=\frac{1}{m} \sum_{j=1}^{p} z_{i j} \\
z_{i j}=\frac{x_{i j}-\min _{j} x_{i j}}{\max _{j} x_{i j}-\min _{j} x_{i j}}
\end{gathered}
$$

gdzie:

$Q_{i}$ - relatywna miara przedsiębiorczości $i$-tego kraju;

$z_{i j}$ - standaryzowana wartość zmiennej diagnostycznej $x_{i j}$;

$x_{i j}$ - wartość $j$-tej zmiennej diagnostycznej dla $i$-tego kraju;

$\min _{j} x_{i j}$ - minimalna wartość $j$-tej zmiennej diagnostycznej;

$\max _{j} x_{i j}$ - maksymalna wartość $j$-tej zmiennej diagnostycznej;

$m$ - liczba zmiennych diagnostycznych.

Relatywna miara syntetyczna przyjmuje wartości z przedziału [0,1]. Wyższa wartość $Q$ oznacza wyższy poziom przedsiębiorczości danego kraju w stosunku do pozostałych porównywanych. Najważniejszym krokiem budowy miary relatywnej jest dobór odpowiednich zmiennych diagnostycznych. Metoda ta pozwala na zagregowanie bardzo dużej liczby takich zmiennych. Daje to ogromne możliwości badawcze. Można bowiem prowadzić obliczenia na bardzo dużym zbiorze danych biorąc pod uwagę dużą grupę krajów porównywanych oraz długi okres badawczy. Kluczowe jednak jest to, aby zmienne diagnostyczne były merytorycznie powiązane z badanych zjawiskiem. Istnieje wiele metod ilościowych doboru i weryfikacji tychże zmiennych, jednakże ważne jest arbitralne podejście badacza i jego znajomość omawianej problematyki. Ograniczeniem może być dostępność danych statystycznych.

W niniejszym artykule kluczem doboru zmiennych diagnostycznych była koncepcja przedsiębiorczości krajowej wynikająca z założeń teorii przedsiębiorczości i przedsiębiorczości międzynarodowej. W opracowaniach podaje się, że na przedsiębiorczość składa się wiele wymiarów: personalny, organizacyjny, środowiskowy (Keupp \& Gassmann, 2009; Zucchello \& Magniani, 2016). Można także wskazać, że na przedsiębiorczość kraju składają się: wymiar przedsiębiorcy, procesu przedsiębiorczego oraz otoczenia biznesowego (Justo, Castro, \& Maydeu-Olivares 2008; Nassif, Ghobril, \& de Silva, 2010). Na tej podstawie do każdego obszaru przedsiębiorczości dobrano zmienną diagnostyczną reprezentatywną. Wybór zmiennych jest arbitralny i nie ostateczny, stanowi jedynie swego rodzaju egzemplifikację danej metody, aczkolwiek należy pamiętać, że może determinować wyniki badań. Rekomenduje się wybór większej liczby zmiennych do badania obszaru, który jest wielowymiarowy i złożony, tak jak przedsiębiorczość krajowa. W niniejszym opracowaniu zaznacza się jednak, iż ma ono charakter badania wstępnego - testowego. W związku z tym, ostatecznie ograniczono się do selekcji czterech zmiennych diagnostycznych:

1. $x_{1}$ - wskaźnik ogólnej przedsiębiorczości na wczesnym etapie (Total Early - Stage Entrepreneurial Activity - TEA - wymiar personalny; wymiar przedsiębiorcy. 
2. $\quad x_{2}$-wskaźnik wzrostu liczby przedsiębiorstw mierzący stopę wzrostu populacji aktywnych przedsiębiorstw $r / r(\%)$ - wymiar organizacyjny; wymiar procesów przedsiębiorczych.

3. $x_{3}$ - wskaźnik przetrwania firm mierzący odsetek firm funkcjonujących co najmniej 2 lata od założenia (\%) - wymiar organizacyjny; wymiar procesów przedsiębiorczych.

4. $x_{4}$ - indeks wolności gospodarczej (Index of Economic Freedom) - wymiar środowiskowy; wymiar otoczenia biznesowego.

Dane zgromadzone do analizy dotyczą sześcioletniego okresu. Dla zmiennej $x_{2}$ i $x_{3}$ zebrano dane $z$ lat 2011-2016, zaś dla zmiennej $x_{1}$ i $x_{4}$ z lat 2012-2017. Poziom kompletność poszczególnych danych wyniósł $85 \%$ - 100\%. Dane brakujące szacowano poprzez interpolację. Dane dla zmiennej $x_{1}$ pochodziły z Globalnego Monitora Przedsiębiorczości (GEM), dla zmiennej $x_{2}$ i $x_{3} z$ Eurostatu, zaś dla zmiennej $x_{4} z$ raportu na temat wolności gospodarczej publikowanego przez The Wall Street Journal $i$ Heritage Foundation. Analiza dotyczy 26 państw unijnych, z pominięciem Grecji i Malty. Te dwa kraje zostały wykluczone z badania ze względu na zbyt duże braki zmiennych diagnostycznych, które uniemożliwiły wiarygodne prowadzenie obserwacji dla tych gospodarek.

\section{PRZEGLĄD LITERATURY}

\section{Przedsiębiorczość kraju jako problem badawczy w perspektywie przedsiębiorczości międzynarodowej}

Przedsiębiorczość jako zagadnienie naukowe wywodzi się z ekonomii, jednakże współcześnie jest rozpatrywany na gruncie różnych dyscyplin naukowych: zarządzania, socjologii, psychologii, antropologii gospodarczej, finansów, itp. (Carlsson et al., 2013). Na potrzeby eksploracji poznawczej przedsiębiorczość kraju może być traktowana jako jeden z poziomów przedsiębiorczości. Przedsiębiorczość bowiem może być analizowana na poziomie jednostek - przedsiębiorców, mikro - firm, mezo - regionów, oraz makro - kraju. Brak jest jednak konsensualnej definicji przedsiębiorczości kraju i de facto przedsiębiorczości w ogóle. Peneder (2009) uważa, że jest ona traktowana zbyt subiektywnie przez badaczy, którzy definiują ją w zależności od własnych potrzeb badawczych. Wielu autorów podkreśla wręcz istny chaos pojęciowy i brak ekwiwalencji pojęcia przedsiębiorczości (Ahmand \& Seymour, 2008; Daviddson, 2003; Shane \& Venkataraman, 2000). Justo, Castro i Maydeu-Olivares (2008) określają przedsiębiorczość kraju jako składową następujących obszarów: 1) skłonności przedsiębiorczych jednostek przejawiających się w powstawaniu, wzroście nowych przedsiębiorstw i przedsięwzięć oraz 2) otoczenia przedsiębiorczego, które determinuje skłonności przedsiębiorcze (Justo, Castro, \& Maydeu-Olivares, 2008). Z kolei Arin, Huang, Minniti, Nandialath i Reich (2015) uważają, że przedsiębiorczość kraju jest sumą multiplikatywnej interakcji pomiędzy kapitałem ludzkim, poziomem rozwoju gospodarczego i instytucjami. Definiowanie przedsiębiorczości nie jest jednak celem samym w sobie a niezbędnym etapem i punktem wyjścia do prowadzenia badań w tym zakresie. Należy zatem mieć na uwadze aplikacyjność konceptualizacji przy próbie definiowania przedsiębiorczości. Brak zgodności co do istoty przedsiębiorczości kraju nastręcza niewątpliwie trudności kwantyfikacyjnych (Acs, Desai, \& Klapper, 2008). W kontekście przedsiębiorczości kraju prowadzone badania mają przede wszystkim charakter badań porównawczych. Komparatystyka jest powszechnie akceptowanym narzędziem poznania w wielu dyscyplinach naukowych. Badania porównawcze przedsiębiorczości krajowej zaś są domeną przed- 
siębiorczości międzynarodowej, obok przedsiębiorczej internacjonalizacji i badań porównawczych nad przedsiębiorczą internacjonalizacją (Allen, 2016; Jones, Coviello, \& Tang, 2011; McDougall \& Oviatt, 1997; Wach \& Wehrmann, 2014). Pierwsze opracowania, w ramach przedsiębiorczości międzynarodowej, dotyczyły analizy przedsięwzięć międzynarodowych, czyli internacjonalizacji i ten obszar badawczy jest najbardziej rozpoznany w przedsiębiorczości międzynarodowej (McDougall, 1989). Przedsiębiorcza internacjonalizacja jest dominującym zagadnieniem do tego stopnia, iż nierzadko utożsamia się ją z przedsiębiorczością międzynarodową jako jej jedyną przestrzenią badawczą. Nie jest to stanowisko prawidłowe. Przedsiębiorczość międzynarodowa jest kategorią szerszą. Mc Dougall i Oviatt (2000) wskazują, że badania przedsiębiorczości międzynarodowej obejmują nie tylko zachowania innowacyjne, proaktywne i ryzykowne, na co wskazywali wcześniej, ale także badania porównawcze zachowań przedsiębiorczych w wielu krajach (McDougall \& Oviatt, 2000). W tym samym czasie Thomas i Mueller (2000) zauważając rosnące zainteresowanie międzynarodową przedsiębiorczością podkreślają potrzebę badań porównawczych, które uwzględniają zarówno popyt, jak i podaż determinującą przedsiębiorczość w różnych krajach i regionach. Według Jones, Coviella i Tang (2011) międzynarodowa przedsiębiorczość zajmuje się zjawiskiem przedsiębiorczej internacjonalizacji, jak również porównaniami międzynarodowymi (porównania międzynarodowe przedsiębiorczości krajowej, przedsiębiorczość migrantów, porównanie przedsiębiorczej internacjonalizacji). Autorzy na podstawie zrewidowanych 232 artykułów dokonali systematyzacji domen badawczych przedsiębiorczości międzynarodowej dzieląc ją na trzy kategorie (Jones, Coviella, \& Tang, 2011): 1) studia nad przedsiębiorczą internacjonalizacją, 2) międzynarodowe porównania przedsiębiorczości krajowej, 3) porównania przedsiębiorczej internacjonalizacji. W chwili obecnej międzynarodowe opracowania naukowe systematyzujące obszary badawczy przedsiębiorczości międzynarodowej wskazują badania porównawcze jako jedne z ważniejszych przestrzeni badawczych w ramach tego obszaru naukowego (Allen, 2016; Perényi \& Losoncz, 2018; Terjesen, Hessels, \& Li, 2013; Wach, 2018). Niestety zupełnie brak jest opracowań w literaturze polskiej na temat przedsiębiorczości krajowej w ujęciu porównawczym. Zagadnienie to nie jest zatem rozpoznane w Polsce.

\section{Problem operacjonalizacji przedsiębiorczości kraju}

Dotychczasowe opracowania na temat przedsiębiorczości krajowej rzadko ujmują ją w sposób kompleksowy, jako sumaryczny efekt oddziaływania różnych wymiarów. Skutkuje to wybiórczym szacowaniem przedsiębiorczości kraju za pomocą pojedynczych wskaźników. Często przyjmuje się dane na temat liczby zakładanych firm, samozatrudnienia, nasycenia firmami, demografię przedsiębiorstw, strukturę własnościową firm, wskaźnik przetrwania firm, itp. (Audretsch \& Thurik, 2001; Dejardin, 2011; Fonseca, Lopez-Garcia, \& Pissarides, 2001; Klapper, Amit, \& Guillen, 2008; ). Nie ma w tym co prawda nieprawidłowości, jednakże trudno uznać, że takie podejście wyczerpująco opisuje przedsiębiorczość danej gospodarki.

Dominującą miarą przedsiębiorczości kraju w dotychczasowych badaniach jest kryterium zaproponowane przez pracowników Bobson College oraz Londong Business School w tzw. Globalnym Monitorze Przedsiębiorczości (Global Entrepreneurship Monitor - GEM). Proponowane podejście próbuje ująć w wymiarze międzynarodowym szerokie spektrum przejawów przedsiębiorczości, takie jak: mierzenie różnic aktywności przedsiębiorczej między gospodarkami, identyfikowanie czynników wpływających na poziom aktywności przedsiębiorczej, poszukiwanie rozwiązań systemowych podnoszących poziom aktywności 
przedsiębiorczej (Àlvarez, Urbano, \& Amorós, 2014). Metoda GEM sprowadza się do gromadzenia danych z dwóch uzupełniających się źródeł: 1) Adult Population Survey (APS), 2) National Expert Survey (NES). APS bada postawy przedsiębiorcze, aktywność i aspiracje jednostek. NES z kolei monitoruje dziewięć czynników determinujących przedsiębiorczość określanych jako Entrepreneurial Framework Conditions (EFCS) (GEM, 2018). Mankamentem opisywanej miary jest niekompletność danych dla dużej grupy państw i lat, co stwarza pewne ograniczenia co do prowadzenia badań dynamicznych.

Àlvarez, Urbano i Amorós (2014) prezentują przegląd literatury na temat badań z zastosowaniem GEM w latach 2000-2012. Na podstawie rewizji prawie 100 artykułów autorzy stwierdzają, że zdecydowana ich większość dotyczy formalnych i nieformalnych oddziaływań instytucjonalnych na przedsiębiorczość, jak również uwarunkowań ekonomicznych. Ponadto autorzy rekomendują łączenie miary GEM ze wskaźnikami pochodzącymi z innych źródeł celem zwiększenia zakresu badawczego i kompleksowości ujęcia. Levie, Auto, Acs i Hart (2013) podkreślają walory miary GEM zauważając, że tak naprawdę przed wprowadzeniem tego mierniki wiedza na temat przedsiębiorczości kraju była dość ograniczona. Inicjatywa GEM przyczyniła się do prowadzenia badań związków i zależności pomiędzy przedsiębiorczością a różnymi ważnymi aspektami gospodarczymi. Zdaniem autorów zdynamizowało to zwłaszcza prowadzenie badań nad korelacją przedsiębiorczości kraju z rozwojem gospodarczym i dobrobytem (Amorós \& Cristi, 2011; Rasool, Gulzar, \& Naseer, 2012; Wong, Ho, \& Autio, 2005).

Inną miarą stosowaną w badaniach przedsiębiorczości kraju jest propozycja World Bank Group Entrepreneruship Survey (GES). Zaproponowany w roku 2007 projekt ma na celu zbadanie wzorca działalności gospodarczej w grupie państw rozwiniętych i rozwijających się (Acs, Desai, \& Klapper, 2008). Intencją inicjatorów badania było zbudowanie bazy danych na temat typologii i cech międzynarodowej działalności gospodarczej w kolejnych latach w oparciu o dane uzyskane bezpośrednio od organu, który zajmuje się rejestracją podmiotów gospodarczych w różnych państwach. Przy doborze metod uwzględniono heterogeniczne ramy prawne i systemy ekonomiczne w oparciu o przyjętą koncepcję przedsiębiorczości, standardową jednostkę miary oraz źródła informacji (Klapper, Amit, Guillén, \& Quesada, 2007). Rodzaj i kierunki badań wykorzystujące miarę Banku Światowego są podobne jak w przypadku GEM jednakże mają o wiele mniejsze znaczenie. Kasseeah (2016) wykorzystuje miarę GES do zbadania wpływu przedsiębiorczości na rozwój gospodarczy, na próbie 125 państw. Podobnie Klapper, Amit, Guillén i Quesada (2007) wykorzystują dane Banku Światowego do zbadania wpływu przedsiębiorczości na rozwój gospodarczy. Widoczne są jednak ograniczenia stosowania zaproponowanej miary Banku Światowego do ewaluacji przedsiębiorczości kraju. Sprowadza się on bowiem, do oceny ilości nowych podmiotów gospodarczych. Trzeba jednak mieć na uwadze zróżnicowanie prawne i formalne w zakresie gromadzenia danych na temat funkcjonowania nowych przedsiębiorstw w różnych państwach. Trudno zatem prowadzić badania porównawcze i relatywizować badania na podstawie tego źródła.

W tym samym okresie Europejski Urząd Statystyczny (Eurostat) w kooperacji z OECD w ramach programu Entrepreneurship Indicator Programme (EIP) opracował zestaw wskaźników opisujących przedsiębiorczość. Celem opracowania jest stworzenie bazy danych do prowadzenia badań porównawczych przedsiębiorczości w trzech wymiarach: uwarunkowania przedsiębiorczości, wyniki przedsiębiorczości, efekty przedsiębiorczości (Eu- 
ropean Commission, 2018). Przedsiębiorczość ma bardzo duże znaczenie w polityce i działaniach gospodarczych Unii Europejskiej. Jest to widoczne nie tylko deklaratywnie ale także poprzez wszelkie programy, raporty $\mathrm{i}$ inne inicjatywy mające na celu promocję przedsiębiorczości w krajach Unii Europejskiej. Przedsiębiorczość prowadzi do powstawania nowych firm, otwierania nowych rynków i rozwijania nowych umiejętności. Według Komisji Europejskiej jest zatem ważną siłą sprawczą wzrostu i konkurencyjności państw europejskich (European Commission, 2012). Przedsiębiorczość krajów unijnych jako temat badawczy nie jest jednak bardzo popularna. Specyfiką opracowań na temat przedsiębiorczości w krajach Unii Europejskich jest traktowanie jej pośrednio bądź opisywanie za pomocą wybranych pojedynczych wskaźników (Ferreira \& Dionísio, 2016; Kincsö \& Radošević, 2017). Przykładem tego może być ilość publikacji na temat przedsiębiorczości opisywanej za pomocą małych i średnich przedsiębiorstw (Floyd \& McManus, 2005; Mc Namara, Murro, \& O'Donohoe, 2017; Serrasqueiro, Nunes, Leitão, \& Armada, 2010; Stouraitis, Harun, \& Kyritsis, 2017). Istotne zatem wydaje się prowadzenie badań na temat przedsiębiorczości krajowej w Unii Europejskiej i tym samym tworzenei wartości dodanej w obszarze badań przedsiębiorczości międzynarodowej i biznesu międzynarodowego.

\section{WYNIKI BADAŃ I DYSKUSJA NAUKOWA}

W dotychczasowych badaniach empirycznych bardzo często wykorzystuje się pojedyncze wskaźniki wyznaczające przedsiębiorczość krajową. W związku z tym w pierwszym kroku analizy podjęto próbę porównania przedsiębiorczości krajów UE na podstawie wybranych miar: wskaźnik TEI, wskaźnik samozatrudnienia oraz wskaźnik demografii przedsiębiorstw. Wyniki badań zaprezentowano w tabeli 1.

Tabela 1. Ranking państw europejskich według wybranych miar przedsiębiorczości (2017)

\begin{tabular}{|c|c|c|c|c|c|}
\hline $\begin{array}{c}\text { Wskaźnik ogólnej } \\
\text { przedsiębiorczości } \\
\text { na wczesnym eta- } \\
\text { pie (2017) }\end{array}$ & $\begin{array}{c}\text { Wzorst populacji } \\
\text { przedsiębiorstw } \\
\text { netto (\%)(2017) }\end{array}$ & $\begin{array}{c}\text { Samoza- } \\
\text { trudnienie } \\
\text { (\%) (2017) }\end{array}$ & $\begin{array}{c}\text { Wskaźnik ogólnej } \\
\text { przedsiębiorczości } \\
\text { na wczesnym eta- } \\
\text { pie (2017) }\end{array}$ & $\begin{array}{c}\text { Wzorst populacji } \\
\text { przedsiębiorstw } \\
\text { netto (\%)(2017) }\end{array}$ & $\begin{array}{c}\text { Samozatrud- } \\
\text { nienie (\%) } \\
\text { (2017) }\end{array}$ \\
\hline Estonia & Litwa & Włochy & Litwa & Hiszpania & Łotwa \\
\hline Łotwa & W.Brytania & Polska & Szwecja & Słowacja & Cypr \\
\hline Holandia & Łotwa & Rumunia & Finlandia & Słowenia & Chorwacja \\
\hline Słowacja & Dania & Holandia & Irlandia & Luksemburg & Austria \\
\hline Polska & Holandia & Hiszpania & Hiszpania & Czechy & Litwa \\
\hline Węgry & Estonia & Czechy & Belgia & Węgry & Francja \\
\hline Rumunia & Cypr & Słowacja & Słowenia & Włochy & Bułgaria \\
\hline W.Brytania & Rumunia & Irlandia & Niemcy & Chorwacja & Węgry \\
\hline Chorwacja & Portugalia & W.Brytania & Austria & Irlandia & Szewcja \\
\hline Luksemburg & Belgia & Portugalia & Francja & Niemcy & Luksemburg \\
\hline Czechy & Bułgaria & Belgia & Dania & Finlandia & Niemcy \\
\hline Portugalia & Szwecja & Finlandia & Włochy & Austria & Estonia \\
\hline Cypr & Francja & Słowenia & Bułgaria & Polska & Dania \\
\hline
\end{tabular}

Źródło: opracowanie własne na podstawie danych Eurostat, GEM.

Analiza porównawcza krajów UE na podstawie trzech wybranych miar nie dostarcza jednoznacznych wyników. Widoczne są istotne rozbieżności w hierarchizowaniu krajów UE 
w zależności od przyjętego wskaźnika. Dla przykładu podać można, iż kraje bałtyckie: Estoani i Łotwa pozycjonowane są najwyżej jeżeli chodzi o wskaźnik wczesnej przedsiębiorczości, zaś w oparciu o wskaźnik samozatrudnienia najniżej, zwłaszcza Estonia. Stosunkowa zgodność wyników widoczna jest dla krajów Wielka Brytania i Holandia, w których to gospodarkach poziom przedsiębiorczości jest wysoki, podobnie dla Niemiec, Austrii, gdzie przedsiębiorczość jest raczej na niskim poziomie. Na tej podstawie zasadne zdaje się być stosowanie miar syntetycznych, które uwzględniałyby różne pojedyncze wskaźniki od odzwierciedlały rzeczywisty obraz poziomu przedsiębiorczości badanych gospodarek.

Punktem wyjścia budowy miary relatywnej jest analiza zmiennych diagnostycznych. Za pomocą statystyk opisowym można zaobserwować ogólne trendy panujące w poszczególnych krajach unijnych w sferach przedsiębiorczości opisywanych za pomocą poszczególnych zmiennych.

Tabela 2. Statystyki opisowe zmiennych diagnostycznych wykorzystanych do budowy miary relatywnej przedsiębiorczości krajów UE (bez Grecji i Malty) w latach 2012-2017

\begin{tabular}{|c|c|c|c|c|c|c|}
\hline \multirow{2}{*}{\begin{tabular}{|l} 
Zmienna \\
Lata
\end{tabular}} & \multicolumn{6}{|c|}{ Wskaźnik aktywności przedsiębiorczej TEA } \\
\hline & 2012 & 2013 & 2014 & 2015 & 2016 & 2017 \\
\hline Max & 14,26 & 13,25 & 11,35 & 14,78 & 17,09 & 19,41 \\
\hline Min & 3,52 & 2,44 & 3,76 & 3,46 & 4,42 & 3,70 \\
\hline Średnia & 7,49 & 7,67 & 7,59 & 7,97 & 8,69 & 8,88 \\
\hline Zmienność & $35 \%$ & $37 \%$ & $30 \%$ & $36 \%$ & $38 \%$ & $44 \%$ \\
\hline Asymetria & 0,95 & 0,21 & 0,17 & 0,84 & 1,00 & 1,38 \\
\hline Odchylenie & 2,58 & 2,81 & 2,25 & 2,86 & 3,31 & 3,94 \\
\hline Zmienna & \multicolumn{6}{|c|}{ Wskaźnik wzrostu liczby przedsiębiorstw (\%) } \\
\hline Lata & 2012 & 2013 & 2014 & 2015 & 2016 & 2017 \\
\hline Max & 12,78 & 14,30 & 6,59 & 12,37 & 4,83 & 9,24 \\
\hline Min & $-8,10$ & $-10,31$ & $-2,26$ & $-5,17$ & $-3,45$ & $-2,16$ \\
\hline Średnia & 1,66 & 0,77 & 0,98 & 1,85 & 1,17 & 2,14 \\
\hline Zmienność & $50 \%$ & $44 \%$ & $125 \%$ & $72 \%$ & $61 \%$ & $111 \%$ \\
\hline Asymetria & 0,51 & 0,40 & 0,72 & 1,03 & $-0,28$ & 1,00 \\
\hline Odchylenie & 4,03 & 4,52 & 2,83 & 3,71 & 2,09 & 2,41 \\
\hline Zmienna & \multicolumn{6}{|c|}{ Wskaźnik przetrwania firm (\%) } \\
\hline Lata & 2012 & 2013 & 2014 & 2015 & 2016 & 2017 \\
\hline Max & 104,72 & 122,58 & 84,40 & 93,15 & 93,15 & 93,15 \\
\hline Min & 46,63 & 47,27 & 49,17 & 48,25 & 44,11 & 48,55 \\
\hline Średnia & 69,59 & 70,03 & 67,49 & 68,73 & 70,17 & 70,07 \\
\hline Zmienność & $16 \%$ & $20 \%$ & $13 \%$ & $14 \%$ & $14 \%$ & $14 \%$ \\
\hline Asymetria & 0,71 & 1,91 & $-0,13$ & 0,30 & $-0,29$ & 0,16 \\
\hline Odchylenie & 11,37 & 13,87 & 8,76 & 9,44 & 9,68 & 9,51 \\
\hline Zmienna & \multicolumn{6}{|c|}{ Indeks wolności gospodarczej WEF } \\
\hline Lata & 2012 & 2013 & 2014 & 2015 & 2016 & 2017 \\
\hline Max & 76,90 & 76,10 & 76,20 & 76,80 & 77,30 & 79,10 \\
\hline Min & 58,80 & 60,60 & 60,40 & 60,30 & 59,10 & 59,20 \\
\hline Średnia & 68,70 & 69,22 & 69,42 & 69,69 & 69,67 & 70,06 \\
\hline Zmienność & $7 \%$ & $7 \%$ & $7 \%$ & $7 \%$ & $8 \%$ & $8 \%$ \\
\hline Asymetria & $-0,23$ & $-0,26$ & $-0,26$ & $-0,30$ & $-0,37$ & $-0,37$ \\
\hline Odchylenie & 4,82 & 4,73 & 4,85 & 4,86 & 5,25 & 5,78 \\
\hline
\end{tabular}

Źródło: opracowanie własny na podstawie danych Eurostat, GEM, WEF. 
Wśród wybranych do analizy zmiennych diagnostycznych można zaobserwować zróżnicowaną zmienność poszczególnych danych. Największe zróżnicowanie widoczne jest dla zmiennej dotyczącej wzrostu liczby przedsiębiorstw, następnie uznać można zróżnicowanie wskaźnika aktywności przedsiębiorczej za przeciętne, zaś w zakresie otoczenia biznesowego i przetrwania firm mówić możemy o dość małym zróżnicowaniu krajów unijnych. Dodać należy, iż istnieje dość znaczący rozstęp pomiędzy wartościami maksymalnymi i minimalnymi poszczególnych zmiennych, co oznacza, iż występują pojedyncze przypadki państw, gdzie odnotowuje się skrajne wartości zmiennych. Wszystkie zmienne diagnostyczne mają charakter stymulant, tzn. wpływają stymulująco na badane zjawisko, dlatego pożądany jest wzrost danego wskaźnika z roku na rok. Taka sytuacja zachodzi dla wszystkich wybranych zmiennych jednakże dynamika pozytywnych zmian jest różna. Jednoznaczna asymetria prawostronna wskaźnika aktywności przedsiębiorczej i wskaźnika wzrostu liczby przedsiębiorstw świadczy o tym, iż większość wartości danych zmiennych jest powyżej średniej. Dla wskaźnika przetrwania firm trudno jednoznacznie zinterpretować ich skośność, zaś w przypadku otoczenia biznesowego mamy do czynienia z asymetrią lewostronną świadczącą o przewadze wartości poniżej średniej dla tej zmiennej.

$\mathrm{Na}$ podstawie zmiennych diagnostycznych obliczono miarę agregatową przedsiębiorczości, co pozwoliło na dalszą i bardziej kompleksową ocenę przedsiębiorczości badanych krajów Unii Europejskiej.

Tabela 3. Statystyki opisowe relatywnej miary przedsiębiorczości krajów UE (bez Grecji Malty) w latach 2012-2017

\begin{tabular}{|l|r|r|r|r|r|r|}
\hline \multicolumn{1}{|c|}{ Miara } & \multicolumn{1}{c|}{$\mathbf{2 0 1 2}$} & \multicolumn{1}{c|}{$\mathbf{2 0 1 3}$} & \multicolumn{1}{c|}{$\mathbf{2 0 1 4}$} & \multicolumn{1}{c|}{$\mathbf{2 0 1 5}$} & \multicolumn{1}{c|}{$\mathbf{2 0 1 6}$} & \multicolumn{1}{c|}{$\mathbf{2 0 1 7}$} \\
\hline Maks. & 0,710 & 0,717 & 0,806 & 0,718 & 0,787 & 0,743 \\
\hline Min. & 0,167 & 0,199 & 0,165 & 0,183 & 0,207 & 0,220 \\
\hline Mediana & 0,392 & 0,439 & 0,455 & 0,438 & 0,464 & 0,392 \\
\hline Średnia & 0,391 & 0,448 & 0,481 & 0,456 & 0,502 & 0,434 \\
\hline Zmienność & $33 \%$ & $31 \%$ & $33 \%$ & $30 \%$ & $30 \%$ & $37 \%$ \\
\hline Asymetria & 0,361 & 0,149 & 0,228 & 0,152 & 0,304 & 0,591 \\
\hline Odchylenie & 0,127 & 0,140 & 0,158 & 0,138 & 0,150 & 0,160 \\
\hline
\end{tabular}

Źródło: opracowanie własny na podstawie danych Eurostat, GEM, WEF.

Według miary relatywnej można ocenić, iż kraje unijne są umiarkowanie zróżnicowane pod względem poziomu przedsiębiorczości. Współczynnik zmienności kształtuje się na poziome $30 \%$ i jedynie w ostatnim roku analizy wyraźnie wzrasta. Asymetria umiarkowana prawostronna świadczy o tym, iż większość państw odnotowuje wyższą wartość relatywnej miary przedsiębiorczości niż jej średnia wartość. Z roku na rok wskaźnik asymetrii prawostronnej się potęguje. Wartość średnia miary relatywnej jest zbliżona do jej wartości mediany. W przypadku 14 gospodarek poziom przedsiębiorczości wzrósł w ciągu badanych lat (Włochy, Wielka Brytania, Szwecja, Portugalia, Łotwa, Litwa, Irlandia, Holandia, Estonia, Czechy, Chorwacja, Bułgaria, Belgia i Austria). W 6 krajach poziom przedsiębiorczości na przestrzeni badanych lat praktycznie nie uległ zmianie (Słowenia, Niemcy, Luksemburg, Francja, Finlandia, Dania) i również dla 6 krajów poziom ten pogorszył się (Węgry, Słowacja, Rumunia, Polska, Hiszpania, Cypr).

Graficzna prezentacja relatywnej miary przedsiębiorczości pozwala w łatwy sposób wytypować gospodarki unijne o najwyższym i najniższym poziomie przedsiębiorczości. 


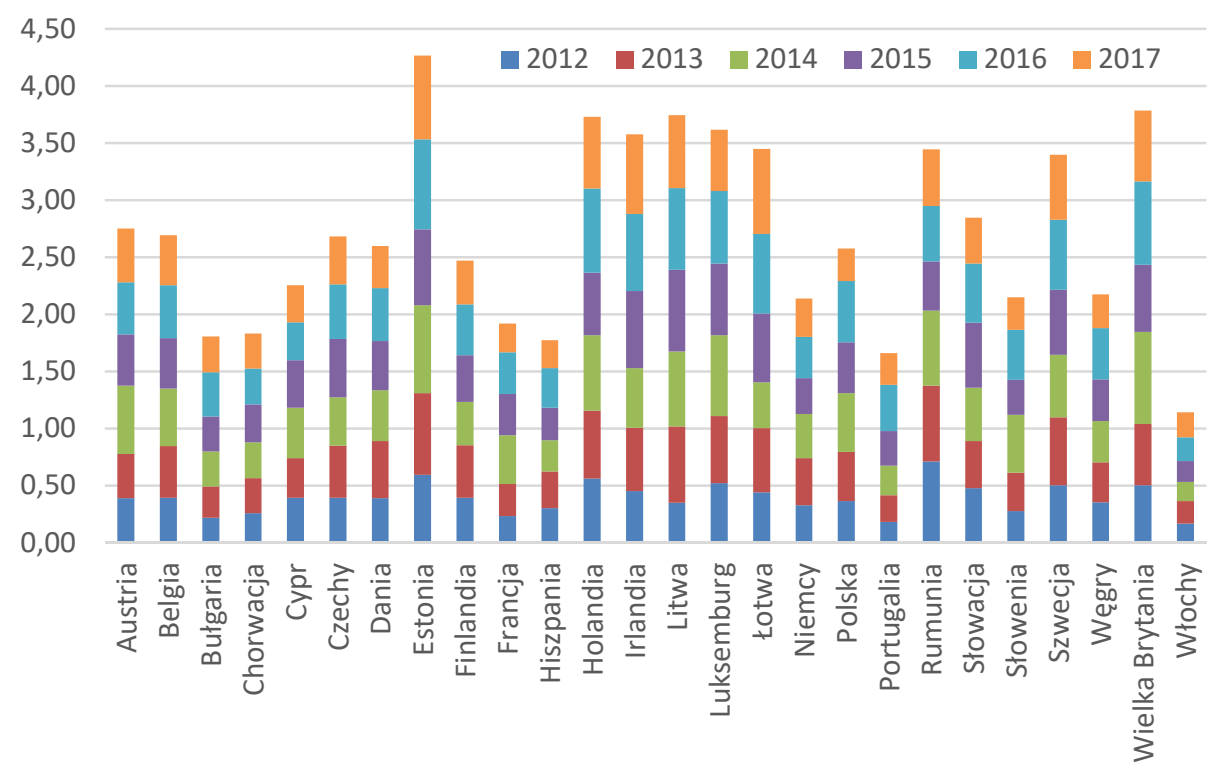

Rysunek 1. Wartości skumulowane relatywnej miary przedsiębiorczości krajów UE (bez Grecji i Malty) w latach 2012-2017

Źródło: opracowanie własny na podstawie danych Eurostat, GEM, WEF

Na podstawie rysunku 1 wytypować można trzy grupy krajów unijnych biorąc pod uwagę poziom ich przedsiębiorczości:

Grupa 1: Estonia, Holandia, Irlandia, Litwa, Luksemburg, Łotwa, Rumunia, Szwecja i Wielka Brytania.

Grupa 2: Austria, Belgia, Cypr, Czechy, Dania, Finlandia, Niemcy, Polska, Słowacja, Słowenia, Węgry.

Grupa 3: Bułgaria, Chorwacja, Francja, Hiszpania, Portugalia, Włochy.

Grupa 1 jest liderem jeżeli chodzi o poziom przedsiębiorczości. W grupie tej znalazły się zarówno państwa z Europy Środkowo - Wschodniej, jak i Zachodniej. Najwyższy poziom przedsiębiorczości mają kraje Estonia i Wielka Brytania. W grupie 3 znalazły się państwa, w których poziom przedsiębiorczości jest relatywnie najniższy. Również i tutaj mamy kraje z tzw. „starej Unii”, zwłaszcza zaklasyfikowano kraje południowej Europy, także tzw. „kraje nowoprzyjęte”. Najniższy poziom przedsiębiorczości występuje we Włoszech, Portugalii i Hiszpanii.

Zaprezentowana miara relatywna przedsiębiorczości daje duże możliwości analityczne. Na jej podstawie możliwa jest dalsza - pogłębiona analiza przedsiębiorczości krajów Unii Europejskiej. Można bowiem dokonywać bardziej szczegółowego grupowania, jak również dyskursywnie oceniać sytuację w poszczególnych grupach i indywidualnych gospodarkach. Narzędzia taksonomii relatywnej eliminują zatem ograniczenia metodyczne innych stosowanych miar, tym bardziej, iż istnieje możliwość arbitralnego doboru dowolnej liczby zmiennych diagnostycznych. Oczywiście musi to mieć uzasadnienie merytoryczne. Kraje unijne są zróżnicowane jeżeli chodzi o poziom przedsiębiorczości, jednakże 
nie jest to bardzo duża dyferencja. Trudno jednak mówić o konwergencji poziomu przedsiębiorczości badanych gospodarek. Dla większości z nich relatywny wskaźnik przedsiębiorczości wzrasta z roku na rok, co świadczy o poprawie ich poziomu przedsiębiorczości. W przypadku pozostałych państw zachodzi regres bądź poziom przedsiębiorczości utrzymuje się na tym samym poziomie przez cały badanych okres.

Porównując wyniki badań z dotychczasowymi opracowaniami można zauważyć, że stosunkowo mało opracowań skupia się na grupie krajów unijnych, a jeszcze mniej traktuje przedsiębiorczość kraju w sposób syntetyczny. Trojak (2013) podejmuje próbę zaprezentowania warunków determinujących rozwój przedsiębiorczości w krajach Unii Europejskiej wykorzystując do tego dane Banku Światowego. Przedsiębiorczość zaś odnosi jedynie do powstawania nowych firm. Autor identyfikuje duże zróżnicowanie poziomu przedsiębiorczości wśród państw unijnych zwłaszcza widoczna jest polaryzacja: kraje rozwinięte - kraje transformacji. Autor zauważa także, że systematycznie poprawia się poziom rozwoju przedsiębiorczości we wszystkich krajach Unii Europejskiej (Trojak, 2013). Wyniki zaprezentowane przez tego autora nie są zatem tożsame z niniejszym opracowaniem. Rodríguez-Gulías, Sousa Gabriel i Rodeiro-Pazos (2018) prezentują wyniki analizy porównawczej przedsiębiorczości i jej uwarunkowań pomiędzy krajami unijnymi (UE28) i nie unijnymi (103 państwa). Postawiona hipoteza badawcza dotyczy wymiarów zarządzania, które determinują przedsiębiorczość rozumianą jako zdolność tworzenia nowych firm. Wyniki badań pokazują zróżnicowanie w grupie badanych państw. Czynniki zarządcze zdecydowanie większe znaczenie mają dla krajów unijnych niż innych gospodarek nie należących do UE. Kardos (2012) bada zależność pomiędzy przedsiębiorczością, innowacyjnością i rozwojem gospodarczym krajów Unii Europejskiej. Punktem wyjścia prowadzonych badań jest innowacyjność małych i średnich przedsiębiorstw (MŚP), co traktować można jako odzwierciedlenie przedsiębiorczości. W opracowaniu potwierdzono pozytywną zależność pomiędzy badanymi zmiennymi.

Kwerenda literatury na temat przedsiębiorczości kraju i metod jej pomiaru pozwoliły zidentyfikować pewną lukę badawczą, którą starano się wypełnić niniejszym opracowaniem. Artykuł ma charakter metodyczny, jego celem jest zaproponowanie i zweryfikowanie metody badawczej, dlatego też nie postawiono w nim hipotez badawczych. Na podstawie jednak rozpoznanej luki badawczej i przeprowadzonego badania własnego można wysunąć trzy twierdzenia badawcze:

T1: Stosowane do tej pory w badaniach empirycznych miary przedsiębiorczości krajów Unii Europejskiej nie dostarczają tożsamy wyników.

T2: Dotychczasowe miary przedsiębiorczości kraju mają pewne ograniczenia i nie ujmują wielowymiarowości problematyki. Zastosowanie narzędzi taksonomii relatywnej pozwala na skonstruowanie zagregowanej i syntetycznej miary.

T3: Kraje Unii Europejskiej są umiarkowanie zróżnicowane jeżeli chodzi o poziom przedsiębiorczości. W większości krajów odnotowuje się wzrost poziomu przedsiębiorczości z roku na rok. Trudne jednak mówić o tym, iż następuje wyrównywanie się poziomu przedsiębiorczości w krajach unijnych ponieważ w analizowanym okresie w niektórych gospodarkach nastąpił regres poziomu przedsiębiorczości bądź nie zmieniał się w całym okresie. 


\section{PODSUMOWANIE}

Analiza porównawcza przedsiębiorczości krajów Unii Europejskiej wpisuje się znakomicie w nurt badań przedsiębiorczości międzynarodowej i zdaje się być bardzo perspektywicznym obszarem eksploracji naukowej. Już samą operacjonalizację przedsiębiorczości kraju uznać można za istotne wyzwanie przyszłych badań na temat przedsiębiorczości. Okazuje się bowiem, że brak adekwatnych miar przedsiębiorczości uniemożliwia prowadzenie kompleksowych badań w tym zakresie, ujmujących przedsiębiorczość kraju w sposób wielowymiarowy. Podejście taksonomiczne pozwala rozwiązać problem jednowymiarowości dotychczasowych badań. Uznać można, iż zaprezentowana miara relatywna przedsiębiorczości spełniła swoją funkcję i powinna mieć zastosowanie w dalszych badania przedsiębiorczości kraju, zwłaszcza, gdy bierze się pod uwagę liczną grupę porównywanych krajów. W tym artykule miara ta stała się narzędziem ewaluacji poziomu przedsiębiorczości krajów Unii Europejskiej. Na jej podstawie stwierdzić należy, że kraje europejskie są umiarkowanie zróżnicowane jeżeli chodzi o poziom przedsiębiorczości. W tym zakresie nie ma też powszechnie obserwowanego podziału na "stare" i "nowe" kraje unijne. Jeżeli chodzi o poprawę poziomu przedsiębiorczości, to jest ona zauważalna dla większości gospodarek, w niektórych jednak następuje regres w tym obszarze bądź też poziom przedsiębiorczości nie zmienia się na przestrzeni badanych lat.

Stwierdzić można, iż przeprowadzona analiza dostarcza interesujących wniosków, które mogą być punktem wyjścia do prowadzenia dalszych badań, bądź też mogą mieć charakter aplikacyjny dla praktyki biznesowej i decyzji politycznych w zakresie opracowania strategii mających na celu wspieranie przedsiębiorczości. Opracowanie nie jest także pozbawione ograniczeń. Przede wszystkim zaznaczyć należy, iż studium ma charakter badań wstępnych. Jest to swego rodzaju próba zastosowania narzędzi taksonomii relatywnej do badań nad przedsiębiorczością krajową. W dalszych pracach należy przede wszystkim zwiększyć ilość zmiennych diagnostycznych, co pozwoli zobrazować pełne możliwości metodyczne omawianej procedury. Dobór zmiennych powinien być poprzedzony ich weryfikacją statystyczną. Zaleca się także prowadzenie badań dla dłuższego okresu, co pozwala zaobserwować realne trendy zachodzące w badanym obszarze i wyeliminować problem incydentalności. Najważniejsze zaś, dotyczy zastosowania danej metody do prowadzenia badań w szerszym kontekście, tj. oszacowania przedsiębiorczości kraju na potrzeby prowadzenia badań przyczynowo - skutkowych.

\section{LITERATURA}

Acs, Z.J., Desai, S., \& Klapper, L.F. (2008). What does „entrepreneurship” data really show?. Small Business Economics, 31(3), 265-281.

Ahmad, N., \& Seymour, R.G. (2008). Defining Entrepreneurial Atibity. Definitions Supporting Frameworks for Data Collection (OECD Statistics Working Papers 2008/01). Paris: OECD.

Allen, I. (2016). International Entrepreneurship Theory: Past, Present and Way Forward. Entrepreneurial Business and Economics Review, 4(4), 93-103. doi: 10.15678/EBER.2016.040406

Àlvarez, C., Urbano, D., \& Amorós, J.E. (2014). GEM research: Achibements and challenges. Small Business Economics, 42(3), 445-465. 
Amorós, J.E., \& Cristi, O. (2011). Poverty and Entrepreneurship in Developing Countries. In M. Minniti (ed.), The Dynamics of Entrepreneurship: Evidence from Global Entrepreneurship Monitor Data (209-230). Oxford: Oxford University Press.

Arin, K.P., Huang, V.Z., Minniti, M., Nandialath, A.M., \& Reich, O.F. (2015). Revisiting the determinants of entrepreneurship: A Bayesian approach. Journal of Management, 41, 607-631.

Audretsch, D.B., \& Thurik, A.R. (2001). What's new about the new economy? From the managed to the entrepreneurial economy. Industrial and Corporate Change, 10(1), 267-315.

Carlsson, B., Braunerhjelm, P., McKelvey, M., Olofsson, C., Persson, L., \& Ylinenpää, H. (2013). The evolving domain of entrepreneurship research. Small Business Economics, 41(4), 913-930.

Davidsson, P. (2003). The Domain of Entrepreneurship Research: Some Suggestions, W: Katz J., Shepherd S.(red.), Advances in Entrepreneurship, Firm Emergence and Growth. (301-331). Amsterdam: Elsevier.

Dejardin, M. (2011). Linking net entry to regional economic growth. Small Business Economics, 33(4), 443-460.

European Commission. (2012). Entrepreneurship 2020 action plan. Reigniting the entrepreneurial Spirit in Europe, Communication from the Commission to the Council, the European Parliament, the European Economic and Social Committee and the Committee of the Regions. COM(2012) 795 final, Brussels.

European Commission. (2018). The Entrepreneurship 2020 Action Plan (Analytical Report). Pobrano luty $2019 \mathrm{z}$ : https://ec.europa.eu/growth/smes/promoting-entrepreneurship/action-plan_en

Eurostat (2018). Pobrano styczeń - luty 2019 z: https://ec.europa.eu/eurostat

Ferreira, P.J.S., \& Dionísio, A.T.M. (2016). What are the conditions for good innovation results? A fuzzy-set approach for European Union. Journal of Business Research, 69(11), 5396-5400. doi: /10.1016/j.jbusres.2016.04.144

Floyd, D., \& McManus, J. (2005). The role of SMEs in improving the competitive position of the European Union. European Business Review, 17(2), 144-150. doi:10.1108/09555340510588011

Fonseca, R., Lopez-Garcia, P., \& Pissarides, C. (2001). Entrepreneurship, Start---Up, Costs and Employment. European Economic Review, 45, 692-705.

Jones, M.V., Coviello, N., \& Tang, Y. (2011). International Entrepreneurship Research (1989-2009): A Domain Ontology and Thematic Analysis. Journal of Business Venturing, 26(6), 632-659. doi:10.1016/j.jbusvent.2011.04.001

Justo, R., Castro, J.O., \& Maydeu-Olivares, A. (2008). Indicators of entrepreneurship activity: some methodological contributions. International Journal of Entrepreneurship and Small Business, 6(4), 604-621.

GEM. (2018). Global Entrepreneurship Monitor. Pobrano grudzień 2018 z: https://www.gemconsortium.org/report/50012

Justo, R., De Castro, J.O., \& Maydeu - Olivares, A. (2008). Indicators of entrepreneurship activity: some methodological contributions. International Journal of Entrepreneurship and Small Business, 6(4), 604-621.

Kardos, M. (2012). The Relationship between Entrepreneurship, Innovation and Sustainable Development. Research on European Union Countries. Procedia Economics and Finance, 3, 1030 1035. doi:10.1016/S2212-5671(12)00269-9

Kasseeah, H. (2016). Investigating the impact of entrepreneurship on economic development: a regional analysis. Journal of Small Business and Enterprise Development, 23(3), 896-916. doi:10.1108/JSBED-09-2015-0130 
Keupp, M.M., \& Gassmann, O. (2009). The Past and the Future of International Entrepreneurship: A Review and Suggestions for Developing the Field. Journal of Management, 35, 600-633. doi: 10.1177/0149206308330558

Kincsö, I., \& Radošević, S. (2017). EU Research and Innovation Policies as Factors of Convergence or Divergence after the Crisis. Science and Public Policy, 44(2), 274-283. doi:/10.1093/scipol/scw063

Klapper, L., Amit, R., \& Guillen, M. (2008). Entrepreneurship and Firm Formation Across Countries. W: Lerner, J., \& Schoar, A. (red.), International Differences in Entrepreneurship (129-158). Chicago: University of Chicago Press.

Klapper, L.F., Amit, R.H., Guillén, M.F., \& Quesada, J.M. (2007). Entrepreneurship and Firm Formation Across Countries (World Bank Policy Research Working Paper No. 4313). Washington: World Bank.

Levie, J., Autio, E., Acs, Z., \& Hart, M. (2013). Global Entrepreneurship and Institutions: An Introduction. Small Business Economics, 42(3), 437-444.

McDougall, P.P. (1989). International versus Domestic Entrepreneurship: New Venture Strategic Behavior and Industry Structure. Journal of Business Venturing, 11(1), 23-40.

McDougall, P.P., \& Oviatt, B.M. (1997). Challenges for internationalization process theory: the case of international new ventures. Management International Review, 37(2), 85-99.

McDougall, P.P., \& Oviatt, B.M. (2000). International Entrepreneurship: The Intersection of Two Research Paths. The Academy of Management Journal, 43(5), 902-906.

Mc Namara, A., Murro, P., \& O’Donohoe, S. (2017). Countries lending infrastructure and capital structure determination: The case of European SMEs. Journal of Corporate Finance, 43, 122138. doi:/10.1016/j.jcorpfin.2016.12.008

Mikuła, A. (2016). Stopień zagrożenia ubóstwem w powiatach i gminach województwa mazowieckiego. Wiadomości statystyczne, 7, 60-74.

Nassif, V.M.J., Ghobril, A.N., \& de Silva,N. S. (2010). Understanding the Entrepreneurial Process: a Dynamic Approach. Brazilian Administration Review, 7(2), 213-226.

Peneder, M. (2009). The Meaning of Entrepreneurship: A Modular Concept. Journal of Industry, Competition and Trade, 9(2), 77-99.

Perényi, A., \& Losoncz, M. (2018). A Systematic Review of International Entrepreneurship Special Issue Articles. Sustainability, 10(10), 3476, 1-26. http://dx.doi:10.3390/su10103476

Rasool, F., Gulzar, A., \& Naseer, S. (2012). Drivers of Entrepreneurship: Linking With Economic Growth and Employment Generation (A Panel Data Analysis). The Pakistan Development Review, 51(4), 587-605.

Rodríguez-Gulias, M.J., de Sousa Gabriel, V.M., \& Rodeiro-Pazos, D. (2018). Effects of governance on entrepreneurship: European Union vs non-European Union. Competitiveness Review: An International Business Journal, 28(1), 43-57. doi: /10.1108/CR-06-2016-0035

Serrasqueiro, Z., Nunes, P.M., Leitão, J., \& Armada, M. (2010). Are there non-linearities between SME growth and its determinants? A quantile approach. Industrial and Corporate Change, 19(4), 1071-1108. doi:/10.1093/icc/dtp053

Shane, S., \& Venkataraman, S. (2000) The Promise of Entrepreneurship as a Field of Research. Academy of Management Review, 25, 217-226.

Stouraitis, V., Harun, M.H.M., \& Kyritsis, M. (2017). Motivators of SME initial export choice and the European Union regional effect in manufacturing. International Journal of Entrepreneurial Behavior \& Research, 23(1), 35-55. doi:10.1108/IJEBR-05-2015-0120.

Terjesen, S., Hessels, J., \& Li, D. (2013). Comparative international entrepreneurship: A review and research agenda. Journal of Management, 42, 299-234. http://doi.org/10.1177/0149206313486259 
Thomas, A.S., \& Mueller, S.L. (2000). A Case for Comparative Entrepreneuship: Assessing the Relevance of Culture. Journal of International Business Studies, 31(2), 287-301.

Trojak, M. (2013). Warunki do rozwoju przedsiębiorczości w krajach Unii Europejskiej. Studia Ekonomiczne, 2, 301-328.

Wach, K. (2012). Europeizacja małych i średnich przedsiębiorstw: rozwój przez umiędzynarodowienie. Warszawa: PWN.

Wach, K. (2018). Teoretyczne podstawy przedsiębiorczości międzynarodowej. W: K. Wach (red.), Internacjonalizacja przedsiębiorstw w perspektywie przedsiębiorczości międzynarodowej (65-92). Warszawa: PWN.

Wach, K., \& Wehrmann, C. (2014). Entrepreneurship in International Business: International Entrepreneurship as the Intersection of Two Fields. W: Gubik, A.S., Wach, K. (red.), International Entrepreneurship and Corporate Growth in Visegrad Countries (9-22). Mickolc: University of Miskolc.

Wong, P.K., Ho, Y.P., \& Autio, E. (2005). Entrepreneurship, Innovation and Economic Growth: Evidence from GEM Data. Small Business Economics, 24(3), 335-350.

Wydymus, S. (2013). Rozwój gospodarczy a poziom wynagrodzeń w krajach Unii Europejskiej - analiza taksonomiczna. Finanse, Rynki Finansowe, Ubezpieczenia, 57, 631-645.

Zucchella, A., \& Magnani, G. (2016). International Entrepreneurship - Theoretical foundations and Practice 2nd Edition. New York: Palgrave Macmillan.

Zucchella, A., \& Scabini, P. (2007). International Entrepreneurship - Theoretical foundations and Practice. New York: Palgrave Macmillan.

\section{Tytuł i abstrakt w języku angielskim}

\section{Quantification of domestic entrepreneurship applying the relative taxonomy tools: An example of European Union countries}

The aim of the article is to present and verify the proposed method of entrepreneurship evaluation at the country level. The proposed method is part of the relative taxonomy and the exemplification will be carried out on a group of European Union countries (EU26) without Malta and Greece. In the theoretical part, critical analysis of literature was used as the research method, and in the empirical part, statistic and tacsonomic methods were used. The evaluation of the level of country's entrepreneurship was based on relative indicator (in other words synthetic). The study was conducted on a group of European Union countries (excluding Malta and Greece). The research period is 20112016 or 2012-2017 depending on the availability of statistic data. The results of the research confirmed the legitimacy of using a relative measure in this type of research. This approach allows for the inclusion of the multidimensionality of the domestic entrepreneurship, as well as for comparing the analyzed countries and their hierarchy. There is a moderate diversification of entrepreneurship in the group. The highest level of entrepreneurship is visible in Estonia, the Netherlands and the United Kingdom, and the lowest in Italy, Portugal and Spain. The added value in the study is to propose a method of evaluating entrepreneurship at country level - the macro level. As a result, the business processes of the European Union were organized and compared. The lack of such empirical studies is noticeable in the literature. It is thus a contribution to the development of research in the discipline of international economics (international entrepreneurship).

Keywords:

JEL codes:
International Entrepreneurship; domestic entrepreneurship; European Union; relative taxonomy; measure of entrepreneurship

F02, L26, N10 


\section{Autor}

\section{Agnieszka Głodowska}

Adiunkt w Katedrze Handlu Zagranicznego, doctor nauk ekonomicznych, autor publikacji z zakresu przedsiębiorczości międzynarodowej i biznesu międzynarodowego, członek kolegium radakcyjnego czasopism krajowych i zagranicznych, zainteresowania naukowe to: przedsiębiorczość międzynarodowa (internacjonalizacja, przedsiębiorczość porównawcza, otoczenie biznesowe), biznes międzynarodowy (ryzyko i płatności w biznesie międzynarodowym).

Adres do korespondencji: Uniwersytet Ekonomiczny w Krakowie, ul. Rakowicka 27, 31-510 Kraków, Poland, e-mail: glodowsa@uek.krakow.pl

ORCID (1) http://orcid.org/0000-0002-5317-8625

\section{Podziękowania i finansowanie}

Publikacja została sfinansowana ze środków przyznanych Wydziałowi Ekonomii I Stosunków Międzynarodowych Uniwersytetu Ekonomicznego w Krakowie w ramach dotacji na utrzymanie potencjału badawczego.

\section{Prawa autorskie}

Ten artykuł został opublikowany na warunkach Creative Commons

Uznanie autorstwa - Bez utworów zależnych (CC BY-ND 4.0 License) http://creativecommons.org/licenses/by-nd/4.0/

Publikacja została wydana przez Uniwersytet Ekonomiczny w Krakowie 